\title{
RADIAL VARIATION IN FIBER LENGTH OF SOME LESSER USED WOOD SPECIES IN NIGERIA
}

A. A. OGUNWUSI

(Received 20 September 2012; Revision Accepted 14 November 2012)

\begin{abstract}
Variations in fibre length of ten lesser used wood species were investigated. The mean fibre length varied from $1.07 \mathrm{~mm}$ in Lannea acida to $2.41 \mathrm{~mm}$ in Sterculia setigera. Four patterns of within tree radial variations in fibre length were observed in the studied species. In pattern one, fibre length increased from the pith to the bark. This was observed in Butyrospermum paradoxum, where fibre length increased from $1.43 \mathrm{~mm}$ in the heartwood to $1.45 \mathrm{~mm}$ in the transition wood and $1.46 \mathrm{~mm}$ in the sapwood; and in Parinarium kerstingii, where fibre length increased from $1.33 \mathrm{~mm}$ in the heartwood to $1.40 \mathrm{~mm}$ in the transition wood and to $1.42 \mathrm{~mm}$ in the sapwood. The same pattern of radial variation was also observed in Detarium senegalense where fibre length increased from $0.95 \mathrm{~mm}$ in the heartwood zone to $0.96 \mathrm{~mm}$ in the transition wood and subsequently to $1.19 \mathrm{~mm}$ in the sapwood zone. In pattern two, fibre length decreased from the heartwood (pith) to the bark as observed in Isoberlina doka and Annogeissus leiocarpus. Fibre length decreased from $1.52 \mathrm{~mm}$ in the heartwood of $I$. doka to $1.40 \mathrm{~mm}$ and $1.31 \mathrm{~mm}$ in the transition and sapwood of the plant species respectively. Also fibre length decreased from $1.30 \mathrm{~mm}$ in the heartwood of $A$. leiocarpus to $1.27 \mathrm{~mm}$ and finally to $1.22 \mathrm{~mm}$ in the sapwood of $A$. leiocarpus. In pattern three, fibre length increased from the heartwood to the transition wood and decreased to the bark. This was observed in Parkia felicoida and Sterculia setigera where fibre length increased from $1.19 \mathrm{~mm}$ in the heartwood of $P$. felicoida to $2.47 \mathrm{~mm}$ to $1.33 \mathrm{~mm}$ in the transition wood and decreased to $1.19 \mathrm{~mm}$ in the sapwood. In Sterculia setigera fibre length increased from $2.47 \mathrm{~mm}$ in the hearwood to $2.50 \mathrm{~mm}$ in the transition wood and decreased to $2.26 \mathrm{~mm}$ in the sapwood of the species. In the $4^{\text {th }}$ pattern, fibre length decreased from $1.49 \mathrm{~mm}$ in the heartwood to $0.96 \mathrm{~mm}$ in the transition wood followed by an increase to $1.19 \mathrm{~mm}$ in the sapwood zone of Mitragyna inermis.
\end{abstract}

KEY WORDS: Radial Variation, Fibre Length, Heartwood, Transition Wood, Sapwood

\section{INTRODUCTION}

The tropical forests in Nigeria have witnessed significant reduction in the availability of economic wood species. The gregarious exploitation of economic wood resources commenced with commercial wood exploitation in Nigeria in 1872 (Aribisala, 1993; RMRDC, 1991). This was complemented by the clearing of forests for housing, infrastructure and agriculture, which proceeded at very fast rates in the 1960's to 1980's. More recently several studies (Aribisala, 1993; Olorunnisola, 2000; RMRDC 2009; Ogunsanwo 2010) have indicated that the overexploitation of the economic wood have had negative impact on capacity utilization in the national forest industries Most of the industries, most especially, the sawmill and furniture industries are now utilizing lesser used wood species, leading to considerable expansion in the number of wood species found in timber markets across the country. Where lesser used wood species are used as replacements of economic wood species, the products are facing acceptance problems in international markets (Jayanelti, 1998; Eastin et al, 2003; Barany et al, 2003). Research studies (Coleman, 1998; Barany, et al 2003) indicated that information on species availability, natural durability, physical properties, working quality and use range which are of utmost importance to manufacturers are lacking. Hence efforts at promoting utilization of lesser used species will not be successful without well documented, readily available concrete information (Arowosoge, 2010).

In view of the above, it is necessary that systematic studies should be carried out on wood quality parameters of lesser used species in the country. As fibres are the principal element responsible for the strength of wood (Panshin and Dezeuw, 1980), it is important to investigate this important parameter in lesser used wood species in Nigerian forests. In diffuse porous hardwoods, an increase in specific gravity is related to fibre characteristics through increase in the proportion of fibres. The amount and quality of fibres has a pronounced effect on wood strength and shrinkage (Panshin and Dezeuw, 1980). Consequently, understanding variation in wood specific gravity, fibre length and related anatomical features provides basis for improved wood utilization (Butterfield et al, 1993). The pattern of radial variation in cell lengths differs across species with radial growth rate (Banan, 1967; Fujiwara and Yang, 2000) which is determined by internal (cambial age) and external factors, such as climatic factors (Nicholls, 1986). In the present study, the patterns of radial variation in the fibre length of ten 
lesser used wood species growing in the Nigerian tropical forests were studied.

\section{MATERIALS AND METHODS}

The hardwood species utilized in the study comprised of Anogeissus leiocarpus (D. C), Guel and Perr; Butyrospermum paradoxum Geartn F. (Aepper); Detarium senegalense J. F. Gmel; Isoberlina doka Graib et. Stapf; Lannea acida, A. Rich; Mitragyna inermis, Parinarium kerstingii Engl; Parkia felicoida keay; Albizia zygia (D. C), J. F. Macbr and Sterculia setigera. The materials for the study were collected from tree species growing in Oke Awon Forest Reserve, near Jebba, Kwara State. The total annual rainfall within the area varied from 1000 to $1250 \mathrm{~mm}$. The tree species were from uneven aged natural stands with ages ranging from 18 to 60 years as deducted from ring counts from samples taken at breast height. Five trees of each species were felled and disc samples, $7.5 \mathrm{~cm}$ thick, were taken at breast height. The sampled discs were immediately wrapped in plastic bags to prevent loss of moisture during transportation

The sample discs were debarked at the laboratory using a kitchen knife. Slivers of wood were obtained from the heart wood, transition wood and sapwood zones by cutting out a thin portion of the wood from the pith to the sapwood of the samples. The samples were macerated in a 1:1 solution of glacial acetic acid to dissolve lignin binding the fibres and in $30 \%$ hydrogen peroxide to bleach the fibres as described by Franklin (1946). The mixture was autoclaved at a constant temperature and pressure of $120^{\circ} \mathrm{C}$ and $1 \mathrm{kgf} / \mathrm{cm}^{2}$ respectively for 45 minutes. The macerated samples were rinsed three times in distilled water and the samples shaken to separate the fibers. A drop of macerated tissue was placed on the microscope slide and covered with a slide cover.

The slides were placed on the stage of a Carl Zeiss single eyepiece microscope with mirror attached for projecting the images on a white paper placed at the same level with the microscope. A total of fifteen whole fibers were measured to the nearest $1.00 \mathrm{~mm}$ at $33 x$ magnification level.

\section{Statistical Analysis.}

The actual length of the fibres was obtained by dividing the length of the measured images by 33 . After the calculation of the fibre length per zone, the mean fibre length per species, range and coefficient of variation in fibre length were calculated.

\section{RESULTS AND DISCUSSION}

The mean, ranges and coefficient of variation of fibre lengths of the sampled species are shown in Table 1. Fibre length varies from $0.95 \mathrm{~mm}$ in the heartwood of D.senegalense to $2.50 \mathrm{~mm}$ the transitional of wood of S.setigera. The mean fibre length varies from $0.91 . \mathrm{mm}$ in D. senegalense to 2.41 in S. setigera. A comparison of the mean fibre values with those of common hardwood species in Europe and America which varies from $0.95 \mathrm{~m}$ to $1.88 \mathrm{~mm}$ (Isenberge, 1951), showed that both values have a very similar distribution. Fibre length is one of the quality parameters for pulpwood. As the hardwoods of similar fibre length have been successfully used for short fibre pulp production, in other countries, these species can be good sources of raw materials for short fibre pulp production locally. The fibre length of $S$. setigera at $2.41 \mathrm{~mm}$ is however higher than those reported for hardwoods general. Thus, Osadare (1997) and Ogunwusi (2003) classified S. setigera as a medium/ long fibre wood species and recommended that research and development be directed towards genetic improvement of the plant species for long fibre pulp production in the pulp and paper industry.

Wood is a natural material and therefore is subject to many constantly changing influences (such as moisture, soil conditions, climate and silvicultural treatment). As a result, wood properties vary considerably. The ten wood species used in this study, exhibited various patterns of radial variation in fibre length. In all, four patterns of within tree radial variations in fibre length were observed. These are.

1. Increase in fibre length from the pith to the bark. This pattern of variation was observed in $B$. paradoxum, $P$. kerstingii and $D$. senegalense (Fig. 1.)

2. Decrease in fibre length from the pith to the bark. This pattern was observed in 1. doka and A.leiocarpus as shown in fig. 2 ..

3. Increase in fibre length from the pith to the transition wood followed by decrease to the bark. This pattern of variation was observed in $P$. felicoida, $L$.acida and $S$. setigera. as shown in fig. 3.

4. Decrease in fibre length from the pith to the transition zone followed by increase to the bark. This pattern of variation was observed in $M$. inermis. (Fig. 4). 
Table 1: Means, Ranges and Coefficient for fibre length of ten lesser used hardwood species

\begin{tabular}{|c|c|c|c|c|}
\hline \multirow[t]{2}{*}{ Species } & \multirow{2}{*}{$\begin{array}{l}\text { Statistical } \\
\text { Parameters }\end{array}$} & \multicolumn{2}{|c|}{ Fibre length Values (mm) } & \multirow[b]{2}{*}{ Sapwood } \\
\hline & & Heartwood & Transition wood & \\
\hline 1. Albizia zygia & $\begin{array}{c}\text { Average } \\
\text { Range } \\
\text { C.V } \\
\text { Mean }\end{array}$ & $\begin{array}{c}1.20 \\
0.61-1.52 \\
2.05\end{array}$ & $\begin{array}{c}1.28 \\
1.67-1.73 \\
23 \\
1.22\end{array}$ & $\begin{array}{c}1.27 \\
0.85-1.67 \\
19.15\end{array}$ \\
\hline $\begin{array}{l}\text { 2, Butyrospermum } \\
\text { paradoxum }\end{array}$ & $\begin{array}{c}\text { Average } \\
\text { Range } \\
\text { CV } \\
\text { Mean }\end{array}$ & $\begin{array}{c}1.43 \\
0.91-1.94 \\
16.58\end{array}$ & $\begin{array}{c}1.45 \\
1.06-2.06 \\
13.05 \\
1.41\end{array}$ & $\begin{array}{c}1.46 \\
0.91-1.94 \\
18.02\end{array}$ \\
\hline $\begin{array}{l}\text { 3. Mitragyna } \\
\text { inermis }\end{array}$ & $\begin{array}{c}\text { Average } \\
\text { Range } \\
\text { CV } \\
\text { Mean }\end{array}$ & $\begin{array}{c}1.49 \\
0.69-2.45 \\
22.66\end{array}$ & $\begin{array}{c}0.96 \\
0.94-2.09 \\
15.24 \\
1.50\end{array}$ & $\begin{array}{c}1.19 \\
0.90-1.96 \\
16.78\end{array}$ \\
\hline $\begin{array}{l}\text { 4.Parinarium } \\
\text { kerstingii }\end{array}$ & $\begin{array}{c}\text { Average } \\
\text { Range } \\
\text { CV } \\
\text { Mean }\end{array}$ & $\begin{array}{l}1.33 \\
0.91-1.88 \\
19.3\end{array}$ & $\begin{array}{c}1.40 \\
0.91-2.60 \\
21.2 \\
1.39\end{array}$ & $\begin{array}{c}1.42 \\
0.85-1.79 \\
19.5\end{array}$ \\
\hline $\begin{array}{l}\text { 5. Lannea } \\
\text { acida }\end{array}$ & $\begin{array}{c}\text { Average } \\
\text { Range } \\
\text { CV } \\
\text { Mean }\end{array}$ & $\begin{array}{l}1.04 \\
0.64-1.67 \\
24.41\end{array}$ & $\begin{array}{l}1.14 \\
0.64-1.18 \\
2.58 \\
1.07\end{array}$ & $\begin{array}{l}1.06 \\
0.67-1.52 \\
22.28\end{array}$ \\
\hline $\begin{array}{l}\text { 6.Sterculia } \\
\text { setigera }\end{array}$ & $\begin{array}{l}\text { Average } \\
\text { Range } \\
\text { CV } \\
\text { Mean }\end{array}$ & $\begin{array}{l}2.47 \\
1.30-3.00 \\
16.41\end{array}$ & $\begin{array}{c}2.50 \\
1.88-3.33 \\
17.31 \\
2.41\end{array}$ & $\begin{array}{c}2.26 \\
1.30-3.76 \\
28.87\end{array}$ \\
\hline 7. Parkia felicoida & $\begin{array}{c}\text { Average } \\
\text { Range } \\
\text { CV } \\
\text { Mean }\end{array}$ & $\begin{array}{l}1.19 \\
0.76-1.61 \\
21.13\end{array}$ & $\begin{array}{c}1.33 \\
0.71-1.58 \\
11.23 \\
1.22\end{array}$ & $\begin{array}{c}1.19 \\
0.80-1.52 \\
16.15\end{array}$ \\
\hline 8. Isoberlina doka & $\begin{array}{c}\text { Average } \\
\text { Range } \\
\text { CV } \\
\text { Mean }\end{array}$ & $\begin{array}{c}1.52 \\
0.85-2.12 \\
20.47\end{array}$ & $\begin{array}{c}1.40 \\
0.78-2.21 \\
2.41 \\
1.19\end{array}$ & $\begin{array}{c}1.31 \\
0.97-1.82 \\
22.52\end{array}$ \\
\hline $\begin{array}{l}\text { 9. Detarium } \\
\text { senegalense }\end{array}$ & $\begin{array}{c}\text { Average } \\
\text { Range } \\
\text { CV } \\
\text { Mean }\end{array}$ & $\begin{array}{c}0.95 \\
0.61-1.39 \\
18.79\end{array}$ & $\begin{array}{c}0.96 \\
0.69-1.24 \\
13.72 \\
0.91\end{array}$ & $\begin{array}{c}1.19 \\
0.70-1.94 \\
23.64\end{array}$ \\
\hline $\begin{array}{l}\text { 10. Anogeissus } \\
\text { leiocarpus }\end{array}$ & $\begin{array}{l}\text { Average } \\
\text { Range } \\
\text { C.V } \\
\text { Mean }\end{array}$ & $\begin{array}{c}1.30 \\
0.94-1.39 \\
14.45\end{array}$ & $\begin{array}{c}1.27 \\
0.87-1.88 \\
18.7 \\
1.27\end{array}$ & $\begin{array}{c}1.22 \\
0.67-1.60 \\
18.7\end{array}$ \\
\hline
\end{tabular}

$\mathrm{CV}=$ coefficient of variation 

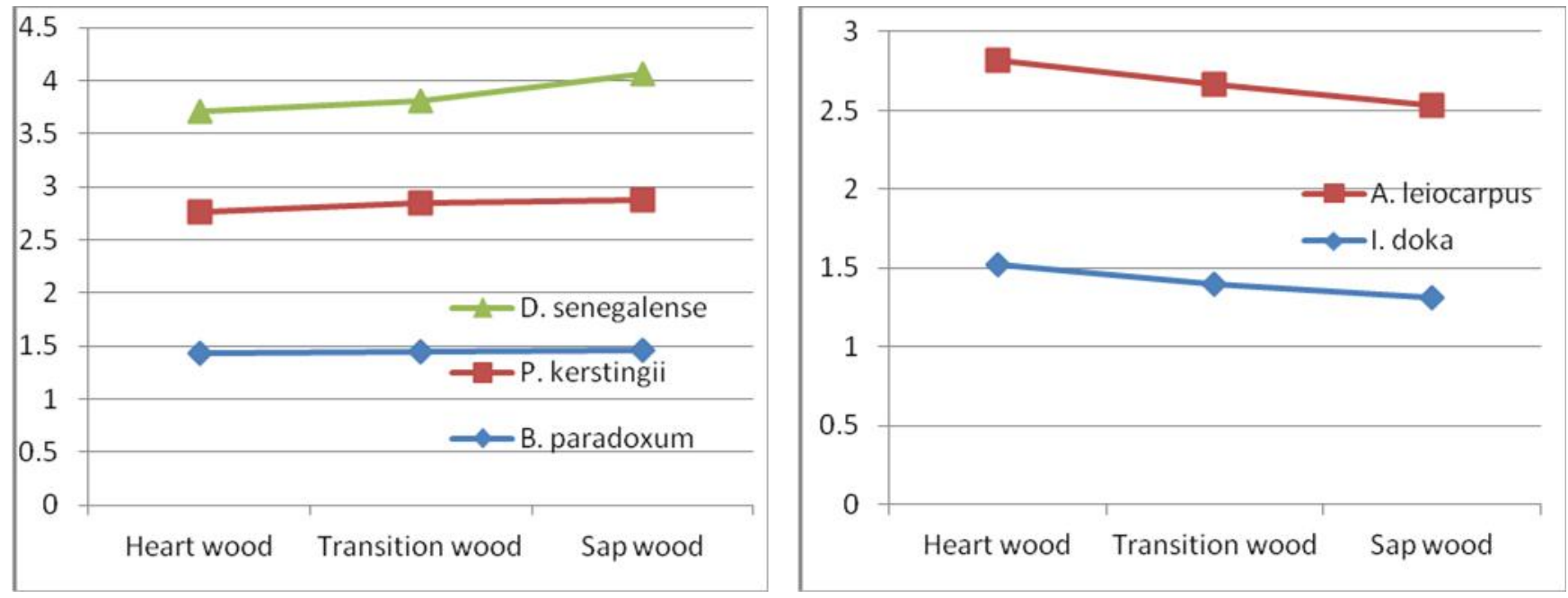

Fig1: Increase in fibre length from the pith to the bark

Fig 2: Decrease in fibre length from pith to the bark

Some of the patterns of within tree variation in fibre length observed in this study have also been reported by several authorities including Kiaei (2011) in the wood and bark of Acer velutinum boiss in Iran and

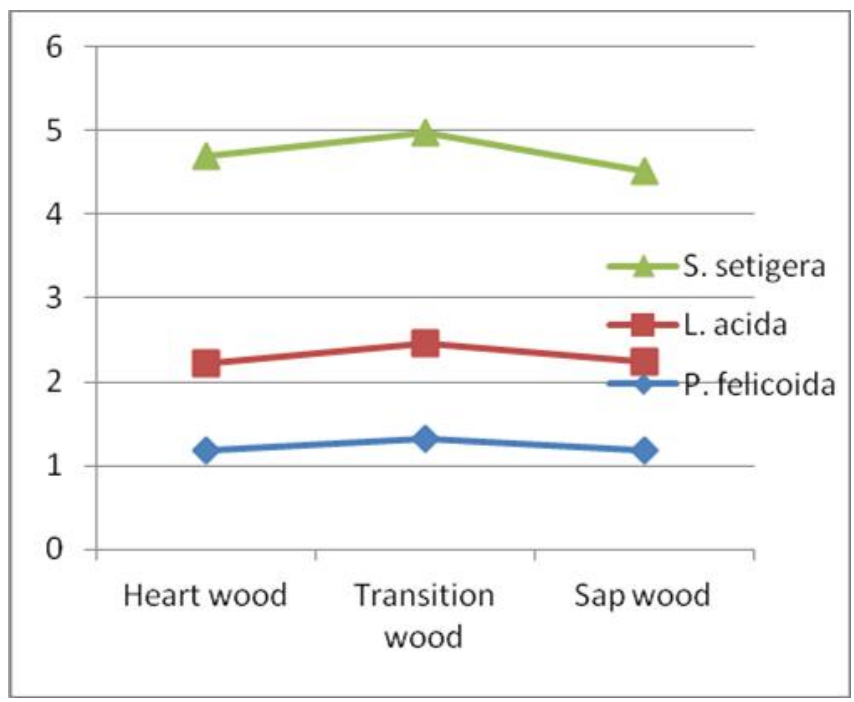

Fig 3: Increase in the fibre length from pith to the transition Wood followed by decrease to the bark

Butterfields et al (1993) in two natural and plantation grown Central American hardwoods; Hyeronma alctorneoides and Vochysia guatamalensis respecively. The radial patterns of fibre length variation observed in 1. doka and A. leiocarpus in which there is a decline in fibre length near in the bark after an initial increase from the pith outwards is the type III pattern described by Panshin and Dezeuw (1980) in timbers such as Fraxinus pennsylvanica, Liriodendron tulipitera, Platanus occidentalism and Salix nigra. Shortening of fibres rear the bark has been attributed to onset of senescence by

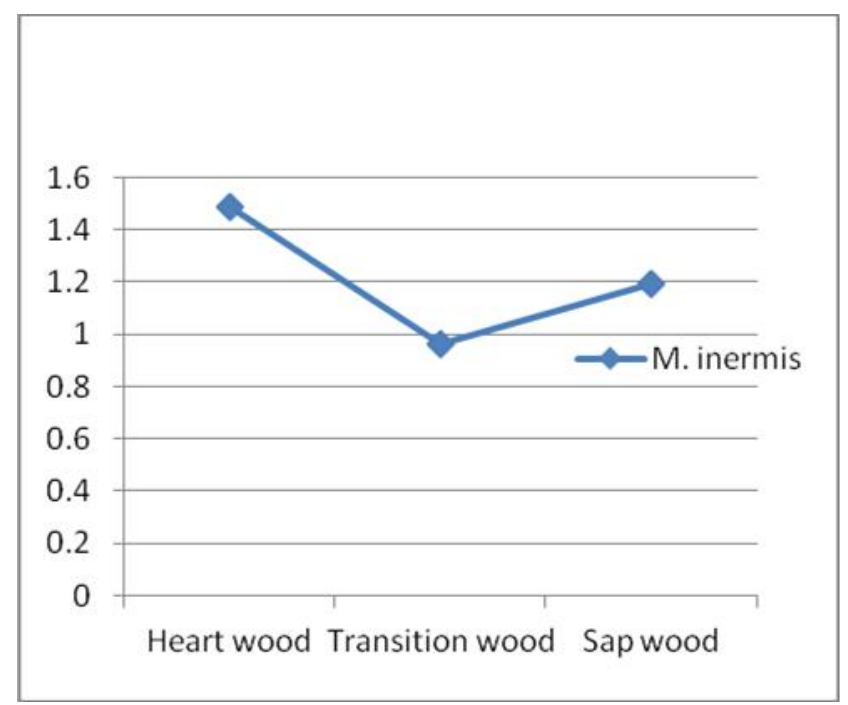

Fig 4:Decrease in fibre length from the pith to the to the transition zone followed by increase to the bark.

earlier workers (Dinwoodie, 1965; Panshin and Dezeuw, 1980). The flat curve in the mature wood showing constant fibre length like the Type 1 described by Panshin and Dezeuw (1980) was not exhibited by any of the species studied. However, a more or less constant increase in fibre length from tree centre to periphery (the type II pattern) was displayed by $P$. kerstingii and $B$. paradoxum and $D$. senegalense

\section{CONCLUSION}


mean fibre values and pattern of radial variation in fibre length in the tested wood species compare favorably with those being used as industrial wood species and for hardwood pulp production in several parts of the globe. This indicated the possible utilization of the wood species in several industries most especially for production of short fibre pulp. However, the fibre length of $S$. setigera at $2.41 \mathrm{~mm}$ makes it a possible raw material for long fibre pulp production.

More recently, there has been increasing interest in the development of wood-plastic composites for use as building materials due to abundance, low cost and process ability of wood as filler. In terms of processing, research and development have shown that mechanical properties and fibre length of wood are sensitive to extrusion parameters such as screw configuration and compounding temperature. Research results so far indicated that short fibre wood species resulted in better mechanical properties of wood plastic composites than long fibre species as they are easier to disperse in the High Density Polyethelene Matrix. This may eventually lead to expansion in the frontiers of the utilization potentials of lesser used hardwood species. Consequently, efforts should be made to ensure that the wood quality parameters of the lesser used hardwoods species be classified in order to expand their industrial application and products acceptability in the global market.

\section{REFERENCES}

Aribisala, O. A., 1993. Raw Materials Revolution and Impact on Industrialization in Nigeria. Mednet Publications Ltd. (1993). Textbook on Raw Materials Sourcing. ISBN $978-024-000-4$. 322

Arowosege O. G. E., 2010. Lesser used wood species and their relevance to sustainability of tropical forests. In S.Kolade Adeyoju and S.O Bada (Eds) Readings in Sustainable Tropical Forest Management pp. Essays in Honour of Professor Labode Popoola. 305-322

Banan, M. W., 1967. Sequential changes in rate of anticlinal, cambial cell length and ring width in the growth of coniferous trees. Can. J. Bot.45: 1359-1369

Barany, M., Hammett, A. L. and Araman, P., 2003. Forest Resource Study Vol. II, Ondo and Ekiti state Forest Inventory, Management, Planning and Recommendations. Technical Report by Forest Management Evaluation and Coordinating Unit (FORMECU), Federal Department of Forestry, Abuja 55pp.

Butterfield, R. P., Crook, R. P. Adams, R. and R. Morris., 1993. Radial variation in wood specific gravity, fibre
Vochysia guatamalensis natural and plantation grown trees. IAWA Journal 14(2) 153-161

Coleman, H. G., 1998. Marketing of Lesser- Species to make an impact on the timber Industry. in Fall, E.G, N.A Darkwa and F.W Owusu (eds) International Conference on Value Added Processing and Utilization of used Timber species. ITTO Project 178/81 Rev 2 (M.I). pp 139-144

Dinwoodie, J. M., 1965. The relationship between fibre morphology and paper properties: a review of literature. Tappi; 48(8): 440-447

Eastin, 1. Addae Mensah, A. G and Appiah, S. K., 2003. The Marketing of Lesser Used Timber Species. In Proceeding of the XX IUFRO Conference, University of Helsinki, Department of Forest Economics, Helsinki, Finland. Publication No 4.

Franklin, G., 1946. A rapid method of softening wood for microtome sectioning. Tropical wood., 88: 33-36

Fujiwara, S. and K. C. Yang., 2000. The relationship between cell length and ring width and circumferential growth rate in five Canadian species. IAWA J. 21:335-345.

Isenberge, I. H., 1951. Fibre dimensions of pulpwoods of the United States and Canada. Texbook published by the Institute of Paper Chemistry, Appleton, Wisconson. 406

Jayanelti, D. L., 1998. Lesser used Timber Species in Construction. In (eds). Fall, E.G., N.A Dakwa and F.W. Owuzu (eds) Proceedings of the International Conference on Value Added Processing and Utilization of Lesser Used Timber Species. Kumasi, Ghana. ITTO Project 178/81 Rev 2 (M.I) 106-112

Kiaei, M and Samariha, A., 2011. Fibre Dimensions, Physical and Mechanical Properties of Five Important Hardwood Plants. Indian Journal of Science and Technology. 4(11): 1460-1463

Nichols, J. W. P., 1986. Within tree variation in wood characteristics of Pinus radiata D. Don Austral. For. Res. J. 16: 361-369

Ogunsanwo, O. Y., 2010. Challenges of wood utilization in Nigeria. In S.Kolade Adeyoju and S.O Bada (eds) Readings in Sustainable Tropical Forest Management. Essays in Honour of Professor Labode Popoola. 293-303 

setigera Growing in the Savanna Belt of Nigeria. Nigeria Journal For. 33 (1) 50-55

Olorunnisola, A. O., 2000. Workshop Structure in the small Scale Furniture Industry in Ibadan metropolis. Journal of Tropical Forest Resources 16(1):46-57.

Osadare O. A., 1997. Strategies For Long Fibre Pulp Production In Nigeria. Nig. Jour. For. 24(1 and 2). $\mathrm{pp} 16-20$

Panshin, A.J. and de Zeeuw. C., 1980. Textbook of wood technology. $4^{\text {ed }}$, NY: McGraw-Hall. 722

RMRDC, 1991. Multi-Disciplinary Task Force Report of the Techno Economic Survey on Wood and
RMRDC, 2003. Multi-Disciplinary Task Force Report of the Techno Economic Survey on Wood and Wood Products. A Publication of the Raw Materials Research and Development Council. 196.

RMRDC, 2009. Multi-Disciplinary Task Force Report of the Techno-Economic Survey on Wood and Wood Products. A Publication of the Raw Materials Research and Development Council. 203 